Distributional Effects of Cash Crop Innovation: The Peripherally Commercialised Farmers of North East Ghana $^{1}$

\title{
Ann Whitehead
}

\section{Introduction}

This is a case study of rural producer households in a specific savannah farming area of North East Ghana which I studied in 1974-75. ${ }^{2}$ In the Bawku District of Ghana's Upper Region, although self provisioning still predominates, the significant agrarian changes in the last 50 years have included various forms of agricultural improvement and, since the 1940s, reliance on an increasing amount of cash cropping as an integral part of the domestic economy. It is also an area which has been experiencing increasingly widespread famine and chronic food shortages. Although the context is one of poor rainfall in the sub Sahel it has nevertheless been argued that the underlying reason for worsening food security is not low rainfall but rather cumulative changes in the rural economy [Shepherd 1979, 1981]. In other words, this case study is in an area in which there appears to be an empirical historical association between market penetration and the decreased food security both of rural households and of the region as a whole, which is manifest in the recent severe effects of environmentally induced food shortages.

The main purpose of my paper is to emphasise just how complex the particular historical experiences of cash crop development which are associated with decreased food security may be. This is not a study which examines, from a basis of base line data about the agrarian system, the changes which have been set in motion by a single set of agricultural interventions. It is rather a study of farmers who have increased the amount of cash crops they grow, often in the context of changed techniques and intensified agronomic practices, at the same time as they diversify in other

\footnotetext{
I am grateful to Simon Maxwell and Alison Evans for very helpful comments on the original workshop paper, although $\mathrm{I}$ am afraid that this version does not reflect their interpretations as much as I would like. I am also grateful to my son, Stephen, for generously looking after himself during a period of illness to enable me to finish this.

${ }^{2}$ Fieldwork was carried out during 1974 and 1975 with the aid of a grant from the then SSRC. In August 1987, I made a short research visit to the Upper Region funded by the Institute of Development Studies and the University of Sussex. My thanks to all these bodies for their financial support, and also to IDS for a period in 1986-87 as a Visiting Fellow which enabled me to work on the issues in this paper
}

ways their source of income and livelihood. It is thus an exemplar of an important variety of cash cropping situations - one in which it is not easy to disentangle the effects of cash cropping from other economic changes as market relations come to characterise rural society. In addition, there have been a whole series of other socio-economic, political and demographic changes during the relevant period. Arguably this characteristic of the Ghana case study - namely that the move within the farming household to the production of crops for cash income has taken place within the context of a whole set of changes within the agrarian society - is much the most common historical experience of the 'cash crop revolution'.

The paper also has a more specific purpose; that of examining more closely one of the assertions of the Food First lobby - namely that there is competition for scarce rural resources between food crop production and cash crop production. I argue that in this area the association between decreased food security, and either commoditisation as a whole, or cash cropping in particular, cannot be interpreted as the result of a straight competition at the household level between growing crops for cash and growing crops for food. For many categories of rural producers, meeting domestic consumption needs may entail the buying and selling of food so that mechanisms which are emphatically not self provisioning may be essential to meeting food security needs in this semi-subsistence situation. Farmers need cash.

It could, however, be argued that there is competition in another sense. Cash cropping (and/or commoditisation as a whole) has introduced important avenues of rural accumulation for some rural producers. This has set in train a series of changes in rural social relations, so as to produce forms of economic inequality which are reproduced through an important series of socio-economic mechanisms. These include the unequal use of the total labour time available to the community by rich households, annual debt relations between households and very unequal positions in the extensive network of clientalist relations which are a major avenue of access to state and other resources. It is these allocation al relations at the community level which lead to food insecurity for some households. 


\section{The Development of the Contemporary Farming System}

The Bawku District is one of the only parts of Ghana to lie in the Sudanic climatic belt, immediately to the south of the Sahel. It is an extremely densely settled area of savannah semi-subsistence rainfed farming with mixed grain and pulse cultivation, and some livestock husbandry [see Benneh 1973]. Most farmers use the hoe and cutlass, but oxen plough farming is also practised. Although millet, sorghum and cowpeas are grown primarily for consumption, and groundnuts are a main source of cash income, in different parts of the District farmers grow small quantities of other cash crops such as rice, tobacco, onions, cotton, tomatoes and kenaf. Many households have non-farm sources of income. The main environmental constraint in farming is the rainfall pattern. There is a single wet season of seven months but overall the rains, especially in the planting season, are very variable, so that in some years only the crops with shorter growing seasons are successful. This has long been an area characterised by periodic, rather localised, drought. In the two years immediately before my study (1972-73 and 1973-74) the District suffered widespread poor rainfall and very low harvests so that there was famine. North East Ghana was feeling the first effects of the Sahel famine. ${ }^{3}$ In subsequent years it continued to suffer from the effects of the drought patterns of the sub-Sahelian Region, and the food problems of rural households have been acute.

These food security problems of the Bawku District have developed in the last 40 years. A study in the 1930 s identified Bawku as exporting food to the neighbouring District which was not able to produce all its own food [Lynn 1937, Ghana Regional Archives 1942]. This 40 years is also the period during which the acreage devoted to cash crops in the District has steadily increased. However, investigating whether this is more than a random association between two otherwise separate trends entails trying to disentangle quite a lot of changes proceeding simultaneously in the rural economy.

The major planned interventions in the agricultural system of the area were begun by the British in about 1940. These were very small in scale and entailed relatively little capital investment. They were very restricted because, as is well known, in their overall strategy for the Colonial Gold Coast, successive British governments used various areas in the Northern Territories mainly as reserves to provide labour for the colonial administration, for the gold mines and for southern cocoa farming [Shepherd 1979, Thomas 1973, Ladouceur 1973]. ${ }^{4}$ Nevertheless

\footnotetext{
${ }^{3}$ Several studies exist of the effects of the drought in Northern Nigeria, [e.g. van Apeldoorn 1981, Watts 1983] but relatively little has been written on the Ghana case.
}

by the end of the 1930s, despite the absence of any direct encouragement of agriculture, other aspects of colonial policy were already having their effects on the farming system. The pre-colonial farming economy was based on self-provisioning with a very limited a mount of trade with regions to the North and South. One of the first effects of British colonial rule was markedly to increase the volume of trading. Rivers were bridged, and transport and communication improved. The Bawku market was encouraged, as were immigrant traders (often foreigners). So, by the 1930s and stimulated by the introduction of head tax, as well as migrating to the south, men had begun spontaneously to grow not insigificant amounts of groundnuts for cash [Ghana Regional Archives 1942].

The success of this expansion of the local farming system encouraged the colonial agricultural officer of the time to press for a scheme in which mixed farming and new techniques were introduced in a linked effort to raise the productivity of the farming system to produce a food surplus and to introduce a source of cash income [see Lynn 1942]. One main avenue was the introduction of bullock plough farming, together with systematic manuring and growing groundnuts for initially compulsory purchase to pay off the debts for the oxen and plough. Although small in scale, this particular innovation was relatively popular and provided the blue-print for subsequent schemes (for example, that of the 1950s through the Kusasis Agricultural Development Committee) [see Benneh 1973]. Mixed plough farming gradually spread so that whereas in 1946 there were 60 registered ploughs in the District, by 1960 there were 2,645 [Ghana Ministry of Agriculture].

Eventually, however, independence brought important changes in the focus of national agricultural policy with a new emphasis on large scale, mechanised and capital intensive schemes. Bawku was far too densely settled to receive any positive attention under this policy. After the demise of the mechanisation model, government efforts in Bawku returned to attempts to diversify and intensify the small-scale farmers' product mix and farming system. With hindsight we can identify a 'more successful' and a 'less successful' strategy within the district as a whole. Relatively more successful were innovations which repeated some of the characteristics of the Colonial model. In the late 1930 s the indigenous smallholder farming system had already developed a system of bush fallowing farming linked to the permanent cultivation of a compound farm around the house which was intensively manured with household and farm yard waste. The colonial mixed farming scheme built on this intensification as well as concentrating on a crop (groundnuts) for

\footnotetext{
${ }^{4}$ In the $1970 \mathrm{~s}$, migrant labour continued to be important in the North East. Approximately $2 / 3$ of households in my study had some male members working away in the south, and a high proportion of male farmers had worked away in the past.
} 
which a market had spontaneously developed. Subsequent extension work and input provision concentrated on more ploughs, new varieties of local crops, irrigated tomatoes and onions and latterly, chemical fertiliser. ${ }^{5}$ Relatively unsuccessful have been the attempts to introduce smallholder production of such crops as cotton and kenaf instituted by the Ghana Cotton Board, or the Fibre Board. In these the parastatals are typically responsible for seed provision, for extension advice and for the collecting, buying and marketing of crops. Although cotton and kenaf were grown by some farmers in the 1970 s, they were fairly unpopular and had not fulfilled even the lowest expections in terms of the amount grown, the rate of adoption or the improvement of farmers' incomes. In part, this is because for several years it has been more profitable for farmers to grow and sell food crops [Laning 1986, personal communication].

This, then, was the state of affairs by the beginning of the 1970s - the decade in which famines on an unprecedented scale began. In addition to these changes in farming, there had been a substantial increase in the number of local employment opportunities and in the volume of market transactions in the local economy. Although relatively little research has been done in this area, one relevant discussion of the 1970s famines is that of Shepherd (1981). Commenting generally on agrarian change in Northern Ghana in the 1970s, he reviews the macro statistical evidence on food production in the Bawku District to argue that there has been an overall decline in food production as commoditisation has proceeded, but a reduced capacity to withstand the kinds of drought induced food shortages, which are environmentally characteristic. The general trend of his argument is thus similar to arguments made by Shenton and Watts (1980), and by Watts (1983) about the sub-Sahelian famine in Northern Nigeria. Shepherd's interpretation needs to be read in the light of two important caveats. Firstly, as Shepherd himself notes, the macro data on agricultural production in Northern Ghana are notoriously difficult to interpret. This is partly because unknown but substantial quantities of food enter parallel markets and cross nearby frontiers. This loss was particularly acute during the 1970 s because of the severity of the drought to the North and because Ghana's economic problems produced an enormously greater value for the CFA franc compared to the cedi. ${ }^{6}$

Equally important to the interpretation of the situation in the North East is the general issue of environmental pressure. This factor has been

\footnotetext{
${ }^{5}$ Within the District as a whole irrigation schemes have been important in changing the profile of farming and of the domestic budget, but this was not the case in the area I studied.

6 Cleveland estimates that in 1978 in the North-East the black market rate for the cedi was 10 times the official rate [Netting, Cleveland and Spier 1978].
}

examined in subsequent discussions by Netting et al. (1978) who emphasise the effects of increased population density, a factor which was particularly apparent on a recent visit I made to the area [Summer 1987]. The British promoted agricultural innovation in the Bawku District (rather than the District to the West which had the food supply problems) because of the intrinsically greater fertility and relative abundance of its farm land. But the district had also functioned as a refuge area for many generations of rural migrants, whose settlement had been eased because of the predominately acephelous forms of social organisation of their ethnic groups. One of the main effects of British domination was that in-migration to this relatively fertile farm area was speeded up. Census figures show that before and during the 1930s there was a massive inflow of migrants from the neighbouring French Territories, and this is also the subject of colonial despatches at the time. Since 1931 high rates of in-migration have been accompanied by high rates of natural increase to produce very substantial rises in population. Netting et al. (1978) gives figures for density of 127 per square mile in 1931 and of 184 per square mile in 1970 .

We may summarise therefore that the Bawku District had experienced a successful form of smallholder innovation - the adoption of groundnuts into the farming system, with the use of ploughs. Although grown mainly for cash, groundnuts were nevertheless a potential source of local food, while those that were sold were consumed largely within the West African Region. There had been some other changes in techniques, and general intensification of land use. While farming remained geared to self consumption, a proportion of the annual farm product was now sold, some of which was of staple food crops, although it is unclear how much of this was 'surplus'. Other changes, notably an increasingly densely settled population, were meanwhile producing an incipient ecological crisis due to the pressure of soil fertility.

\section{Household Food Security}

At the time of my research in the mid-1970s, rural households in the communities I studied in the Bawku District were attempting to meet their annual consumption needs through a mixed profile of self provisioning, and of raising cash income through agricultural commodity production and from other sources, (e.g. trade, artisanal production, wage labour and migrant labour). They pursued a 'semisubsistence' strategy to the extent that producing enough staple food for household needs was a stated goal of farming. Indeed, this objective was bound up with cultural norms about the economic rights and responsibilities of household members to each other.

Each farming unit is composed of 'household' and 
'private' farms and the household farms, whose crop fills the granary which nominally at least feeds all the members of the farming unit, has the first call on men's and women's labour [Whitehead 1981]. However, some food (including in some households - staple), some other consumption needs and some inputs to farming are also bought. The commitment to self provisioning in staples occurs in the context of recurring environmental risk. The annual farming cycle is marked by a hungry season or hunger gap of varying duration. This is the period between the end of the food supplies for one year and before the first harvest of the next. This hunger gap is a characteristic of the Savannah farming of West Africa [Gordon 1972, 1981; Hill 1972] where its duration and severity are dependent on the very variable pattern of rainfall during the growing season.

The existence of a hungry season has been reported consistently by modern commentators on NE Ghana who have sometimes documented the regular drop in body weights of adults and children in the months before the harvest [Hunter 1967; Gordon 1981:7]. It has often been noted that the hunger gap means that calorific intake and body strength are at their lowest when farm work is at its hardest. One main signal of the hunger gap is the annual cycle in food prices in local markets. This annual price cycle has led to local speculation on the grain market in which some farmers and traders buy up staple in the period immediately after harvest to release it on the market as prices rise later in the year. ${ }^{8}$

Local culture recognises the existence of the hunger gap by naming it, by characterising the success or failure of the farming year by its duration and by the presence of a number of established mechanisms for bridging it. These mechanisms have changed over time [Whitehead 1984] such that there is an increasing reliance on buying in staple to meet the shortfall in own produced food.

In the farming season 1974-75 (in which rains were adequate) I collected data on the food security status of households in one of the communities I was studying. Table 1 shows that, during that year, one fifth of the households had an annual own produced surplus; one third of the households brought food for at least one and up to two months during the hungry season, while 30 per cent bought food for between three and four months. Table 2 shows the reported sources of finances for those who have to purchase staple during the hunger gap, in which it is clear that a main strategy is to sell off small livestock which are

\footnotetext{
7 The West African hunger season is difficult to interpret and there is certainly controversy as to whether it is produced mainly by cultural practices or mainly out of food shortfall [Hunter 1967, Gordon $1981]$.

${ }^{8}$ See Hill 1972; Clough 1980; 1981 for descriptions of similar effects in N. Nigeria.
}

Hungry Season Buying 1974-75

\begin{tabular}{|lcc|}
\hline $\begin{array}{l}\text { Period for which } \\
\text { Bought Staple }\end{array}$ & $\begin{array}{c}\text { Number of } \\
\text { Households }\end{array}$ & Percentage \\
$\begin{array}{l}\text { Total number } \\
\text { households }\end{array}$ & 54 & $100 \%$ \\
No information & 5 & \\
\hline $\begin{array}{l}\text { Did not buy } \\
\text { Up to two months }\end{array}$ & 12 & $20 \%$ \\
$\begin{array}{l}\text { From two to more } \\
\text { than three months }\end{array}$ & 19 & $35 \%$ \\
$\begin{array}{l}\text { Bought food, but no } \\
\text { information as to how } \\
\text { long }\end{array}$ & 3 & $26 \%$ \\
\hline $\begin{array}{l}\text { Food surplus households } \\
\text { Food deficit households } \\
\text { Severe deficit households }=\text { bought staple }\end{array}$ & \\
\hline
\end{tabular}
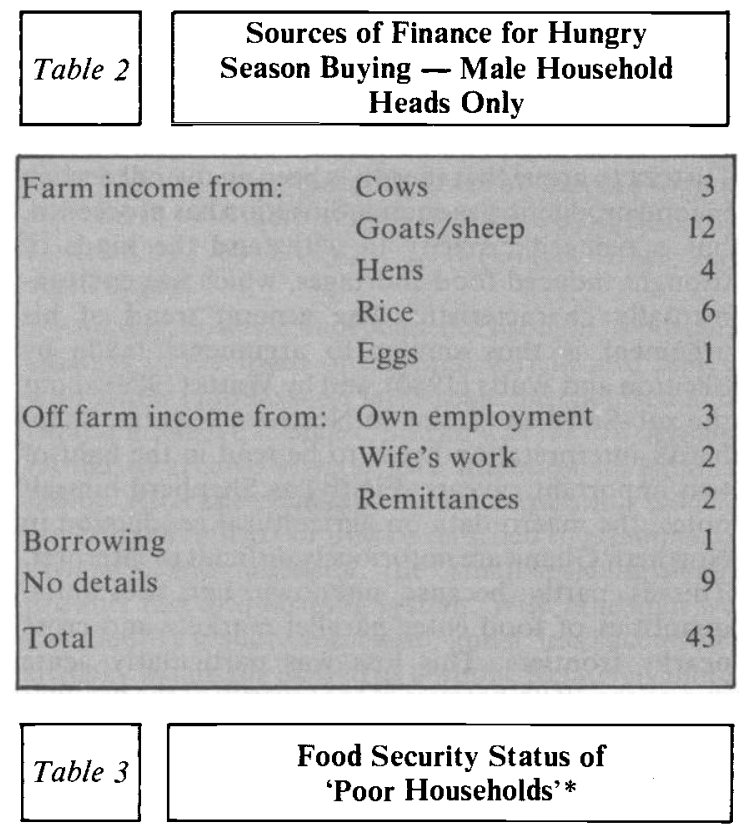

Total number of 'poor' households

Food security status not known

'Food deficit' (1-2 month buying)

'Severe deficit' (3-4 months buying)

* Informants' ranking of households as 'poor' or 'not poor'. 
used as a main savings and hedge against food and other shortfalls. Livestock prices are at their lowest when food prices are at their highest. Cash crops provide a source of income for food buying in only a minority of cases. There is, however, another important consequence of the hunger gap. Some households reach the new planting season with insufficient seed, so that they have to borrow in order to plant. Usually they borrow from their more fortunate neighbours who have been enjoying a food surplus. Repaying this debt, however, is often the first call on the subsequent harvest. Hence indebtedness can contribute to a new year's hunger gap.

Other observations suggest that inequality in terms of food security may conceal socio-economic differences of a more deep-rooted kind - for example the cultural labels which existed to describe economic inequality. Within the community there was widespread agreement as to which households could be described as 'poor' and which 'not poor'. Table 3 documents the relationship between those subjective categories and food security as I measured it in 1974-75. This table shows a close correlation between objectively defined (though self reported) poor category, and suggests the need to examine socio-economic inequality more closely.

\section{The Dynamics of Contemporary Economic Inequality}

Economically and politically the pre-colonial Kusasi, who were the numerically dominant ethnic group in the Bawku District, were a highly egalitarian people. ${ }^{9}$ They had a stateless society, organised on the basis of lineages and clans, and they had no chiefs and no elite. There was local trade which served to distribute most required items, but external trade, which might have led to accumulation, was limited. Colonial rule and its associated political and economic changes disrupted this homogeneity. The introduction of chiefs imposed new forms of hierarchy whose effect on kinship and community relations was wide-ranging and subtle, while the overall effect of economic change was to create certain forms of socio-economic differentiation.

This differentiation, though discernible and significant, is quite limited. In the mid-1970s household labour was still central to the farm enterprise. There was very little agricultural employment, no landlessness, and no buying and selling of land. Nevertheless not only

\footnotetext{
9 The ethnic situation in Bawku is complex, as befits a refuge area of high in-migration. The politically most important group were the sections and chiefships of Mamprussi origin whose traditional social organisations had been state in form. Pre-colonially the Mamprussis had exercised some political sovereignty over the acephelous groups of the area, and especially the Kusasi. The extent of this political dominion is the subject of controversy both among local politicians and commentators [Symes 1937; Kelly 1977; Drucker-Brown 19751
}

was access to these resources skewed, but the processes of resource allocation themselves suggested a dynamic of potentially growing inequality. In relation to land for example, although the acreages of the 'household' farms were not dramatically unequal between households, (especially when the very wide variation in household size is taken into account) the acreages that men farmed 'privately' varied between 0 and 25 acres. Much, though not all of this private farming is of 'cash crops', so that there is much greater variation between individual men in cash crops grown compared to staple crops

Farming these higher acreages poses a problem of labour supply. Kusasi farmers rely on labour both from within and outside the household. It is a definite advantage, then, to belong to a household with a large number of male adult members. But much of the demand for labour input during the farming season, especially for the heavy weeding work, is met by calling communal labour parties, which may be large in size. These require the host farmer to provide a meal and beer, involving a substantial outlay of resources. In the 1970s I found that men in rich households called many more labour parties, which might mobilise large numbers of men (30-40). These groups were for weeding staple and cash crops. Poor men, while calling no or few labour parties, themselves nevertheless went out repeatedly to the communal labours of their neighbours and kinsmen. In the changed circumstance of a more productive agriculture exchange, labour, rather than being redistributed according to need, has become a means of redistributing labour unequally between households, some of which produce much more surplus than others. Labour time is effectively pulled out of food deficit households, and into those of food surplus households, enabling them to consolidate their position.

The broad effects of economic changes which include the development of markets, the establishment of cash crops, and changed agricultural techniques appear to have been to create avenues for rural accumulation. Relative success at accumulation produces the categories of 'poor' and 'not poor' households which differ impressionistically from one another in a number of ways. 'Not poor' households are larger than average in size, with more adult men and women, married and unmarried. As well as tending to crop larger acreages than other farmers, they also farm more cash crops, and have the most lucrative off farm incomes, including more women brewing millet beer for sale at home or market.

Rich households also almost invariably possess one or more of the ploughs and bullocks which have been available in the area for 35 years, although latterly in increasing numbers. In the $1970 \mathrm{~s}$, well established 'rich' households had usually acquired their first ploughs early on in this period and an important step 
on the ladder of accumulation appeared to be the change to plough farming. The main explanation for differences in takeup of ploughs in the early years lie in both political and economic spheres. Those who got ploughs were likely to be in close contact with the colonial officials, but they also needed to possess appropriate livestock. Although there were probably not substantial differences between households and lineages in the non-monetary reserves of resources that livestock herds represented in the 1940s, nevertheless there were some differences, and we may surmise that the innovations were taken up selectively on this basis. Plough farming has not incręased productivity per unit of land but has increased total yields through the increasing acreages farmed which has encouraged farmers to retain household members as part of the labour supply, and to use the network of social relations to mobilise exchange labour. In the conditions of the 1970 s therefore, farming success was related to position in the predominately clientalist or kinship relations which constituted the rural social network.

In addition to their role in recruiting labour, they were also important in relation to the acquisition of land. Although as mentioned earlier land was not bought and sold, it had become scarce as shown in the reduction of fallowing periods, and in some farmers' views that shortage of land was their main problem. Men mainly used their political and kinship links in their considerable and competitive struggles to obtain access to farms which were not immediately around their compounds. It was the outcome of those struggles which produced skewed acreage distributions for cash cropping.

These findings do have significant implications for the issue of the relation between staple crop and cash crop production in the NE Ghana case. The skewed distribution of land and labour resources between households means that significant competition does not exist at the household level. Food security status and success at cash cropping tend to vary in the same direction, and there is certainly a strong link at the household level between successful cash crop production and annual staple surplus production. Food deficit households were generally not farming enough land to produce enough staple or enough income through cash crops.

\section{Conclusion}

In the paper I have argued that there is an historical association between market penetration, and increased food insecurity of rural households, manifest in this area in increasingly difficult to withstand ecologically induced famines. It may be difficult to distinguish the effects of cash cropping from progressive commoditisation in the rural economy, and from other environmental and social changes. Interpreting the NE Ghana case is difficult because reliable macro data on agricultural production is absent. Examining household level data reveals the problematic nature of the cash crop/food crop division in relation to the economic modelling of contemporary self provisioning. Meeting domestic consumption needs emerges as a complex set of decisions in which the buying and selling of staple foods may be an essential aspect of meeting food supply needs. This raises the problem of the level at which the competition between cash crops and food crops is conceptualised. Any correlation between decreased food security and increased cash cropping relates not to household level allocation decisions, but to allocation at the community level. The use of land, labour and capital resources by individual households is mediated by social relations of allocation within the community. But these do not arise from what is conventionally regarded as a differentiated socio-economically population. Although in my general descriptions I stressed the colonial and post-colonial marginalisation of the area, state resources into agriculture and the form of intervention were not insignificant as far as the local populations were rural concerned. As observable factor affecting the relative contemporary socioeconomic positions of households was their chronological progress within the framework of agricultural developments that had taken place. Economic success was associated with the early and consistent use of improved techniques and technology and the longterm unfolding of the benefits of increased yields which this entailed. In particular, households which had got bullock ploughs early were more likely to be in a stronger economic position by the 1970 s. This raises the significance of what categories of socio-economic differentation are commonly conceptualised in relation to rural processes of inequality. In this case a relatively slow development of inequality is potentially associated with food insecurity for a stratum of households, and hence for the region as a whole.

\section{References}

Benneh, G., 1972, 'The Research of Farmers in Northern Ghana to the Introduction of Mixed Farming: A Case Study' Geografiska Annaler (Stockholm) 54, 2: 43-61

-1973, 'Small Scale Farming Systems in Ghana', Africa 43, 2: $136-145$

Clough, P., 1980, 'Indebtedness among the Rural Hausa: A Case Study', Research Note, Queen Elizabeth House, Oxford

-1981, 'Farmers and Traders in Hausaland', Development and Change, vol 12 no 2

Drucker-Brown, 1975, 'Ritual Aspects of Mamprussi Kingship'. African Social Research Documents, Leiden

Ghana Ministry of Agriculture, Bawku District Annual Reports Ghana Regional Archives, (R. Smith, Agricultural Officer), Agriculture in Kusasi', Tamale RAT1/456 
Gordon, G. M., 1972, 'An Evaluation of Nutrition Education Given to Pregnant and Weaning Women in Six Communities in the Upper Region of Ghana', MSc Thesis, University of Ghana, Legon

-1981, 'The Hungry Season in the Savannah of West Africa', Development Digest, 5

Hill, P., 1972, Rural Hausa. A Village and a Setting, Cambridge University Press

Hunter, J. M., 1967, 'Seasonal Hunger in the West African Savannah', Transactions of the Institute of British Geographers

Kelly, R., 1977, 'The Bawku Dispute: A Case Study in Local Level Politics' unpublished ms.

Ladouceur, P. A., 1973, 'Regionalism and Political Development in Northern Ghana: A Study of the Effects of Social and Economic Disparities', DPhil Thesis, University of Sussex

Lynn, C. W., 1937, 'Agriculture in North Mamprussi', Bulletin no 34, Department of Agriculture, Gold Coast

-1942, 'Agriculture in North Mamprussi', Farm and Forest, 3

Netting, R., Cleveland, D., and Spier, F., 1978, 'Agricultural Intensification in the West African Savannah', USAID Report
Shenton, B. and Watts, M., 1980, 'Capitalism and Hunger in Northern Nigeria', Review of African Political Economy no 15

Shepherd, A. W., 1979, 'The Development of Capitalist Rice Farming in Northern Ghana', PhD Thesis, Cambridge

-1981, 'Agrarian change in Northern Ghana: public investment, capitalist farming and famine' in $\mathbf{J}$. Heyer, P. Roberts and G. Williams (eds) Rural Development in Tropical Africa, Macmillan, London

Symes, F., 1937, 'A Short History of the Kusasi', ms.

Thomas, R. G., 1973, 'Forced Labour in British West Africa: The Case of the Northern Territories of the Gold Coast', Journal of African History, vol 14 no 1

Van Apeldoorn, J. G., 1981, Perspectives on Drought and Famine in Nigeria, George Allen and Unwin, London

Watts, M., 1983, Silent Violence, University of California Press

Whitehead, A., 1981, "'I'm Hungry, Mum”: The Politics of Domestic Budgeting', in K. Young, R. McCullugh and C. Wolkowitz (eds.), Of Marriage and the Market, CSE Books, London

-1984, 'Gender and Famine in West Africa' unpublished paper for the DSA annual conference, Bradford 